\title{
Trends of Women's Participation in Economic Activity of Bangladesh: Status and Disparity
}

\author{
Iftekhar Mohammad Shafiqul Kalam, Assistant Prof. \\ Mohammad Mastak Al Amin, Senior Lecturer
}

BRAC University, Bangladesh

doi: 10.19044/esj.2016.v12n35p50 URL:http://dx.doi.org/10.19044/esj.2016.v12n35p50

\begin{abstract}
In Bangladesh - despite having significant progress in reducing poverty over the past three decades and increase in the number of women in the paid workforce, there remain many areas where gender disparities still exists. Study shows women's earnings to be approximately $58.5 \%$ of men's. Women in Bangladesh remain particularly vulnerable to live in poverty. Socially prescribed roles have limited women's access to economic resources such as capital, skills, and marketing know how. However, social attitudes are changing, and women in Bangladesh are taking advantages of new opportunities for economic and social development with far reaching effects.
\end{abstract}

Keywords: Women, Disparities, Development

\section{Introduction}

Women's participation in economic activity is considered one of the most important indicators to assess the status of women's empowerment, along with other social indicators like status of gender based violence, participation in decision making process and so on. Universally it is anticipated that economic solvency - attained from involving in economic activity, to strengthen women's role in decision making authority commencing from macro level to national level.

Significant progress has been made in reducing poverty in Bangladesh over the past three decades; however, there is concern over the extent to which women have benefited from these economic growth and human development efforts. Women in Bangladesh remain particularly vulnerable to live in poverty. Socially prescribed roles have limited women's access to economic resources such as capital, skills, and marketing know how (ADB, 2004). However, social attitudes are changing, and women in Bangladesh are taking advantages of new opportunities for economic and 
social development with far reaching effects. In Bangladesh despite increases in the number of women in the paid workforce, there remain many areas where gender disparities are marked. This paper discusses the trends of women's participation and status from different dimension in the workforce and existing wage disparities.

\section{Current trends in women's participation in economic activities:}

Women - especially from poor households are moving in to the formal wage labour market in increasing number. Kabeer (2012) stated that women's involvement in the labour market is not often her individual choice.The 1999-2000 labour force survey reveals that women's participation in the paid labour force rose from $15.8 \%$ (in 1995/96) to $23.9 \%$ (in 1999/00) (BBS, 2002). However under employment is high in general in Bangladesh with $35 \%$ of the total labour force working less than 35 hours during a reference week; these rates are higher in the agricultural sector (46\% overall) and are particularly acute for women of whom $72 \%$ are underemployed. Women also move in and out of the paid work force more frequently for several reasons, many of which are intrinsic to low - skilled sectors. Klasen (2012) found that women with lower education mostly engaged in low wage employment in India. Day labourers in the agricultural sector are hired mostly only on seasonal basis, and in manufacturing sectors employment may be informal with short - term engagements and unregulated working conditions.

Table 1: Proportion of women in selected sectors of the economy in Bangladesh

\begin{tabular}{|c|c|}
\hline Sector & Women as \% of total work force in each sector \\
\hline Total & 19.2 \\
\hline Public / autonomous & 11.9 \\
\hline Formal sector (private) & 6.2 \\
\hline Informal sector (private) & 22.7 \\
\hline Non profit institutions & 44.2 \\
\hline
\end{tabular}

Source: LFS 1999 - 2000: total proportion excludes temporary and day labourers

Amin (2005) showed that female labour force participation has increased pointedly in Bangladesh owing to better payment of home-based economic activities. Although the number of women participating in employment sector is increasing, they are still outnumbered by their male counterpart in numbers in most of the major employment sectors (Table 1). In 2011, ADB and ILO showed that gender disparities in Asian countries are entrenched not only due to social and cultural norms but also embedded in the policy focus as well as institutional environment (Islam, 2011). Rahman (2013) showed that in Bangladesh women's wage was only $66 \%$ of male wage in 2006 where as it increased to 84\% in 2010. However, in case of 
salary there is a significant disparities between male and female, women's average salary was only 54\% of male salary in 2010.

Traditionally, women's employment opportunities outside the homestead have been very limited. Much of the labour formerly performed by women at household level (e.g. in rice milling, weaving) has been displaced by technological change and mechanisation. Organised food for work and other employment schemes provide some employment for impoverished rural women, but are limited in scope and duration. In some areas, landless women collectively lease land or ponds to engage in activities such as livestock and poultry rearing, fishpond cultivation and vegetable production (Jahan, 1989). There is also some group ownership/operation by women of rice and oil mills. Some younger women with formal education are finding employment in non-traditional spheres such as education, health and family planning and development extension work.

The lack of employment opportunities in rural areas is also manifested in increasing rural-urban migration, including that of femaleheaded households. Migrant women find employment in domestic service, a variety of informal sector occupations (including prostitution) and casual unskilled labour, e.g. in the construction industry.

Some, mainly younger women in urban and semi-urban areas are taking up factory employment in export-oriented industries such as garments, where the labour force is predominantly female (Eggen, 1998). Other potential growth sectors in manufacturing industry (e.g. shrimp processing, leather goods, toys) may employ significant numbers of women. However, most women in manufacturing still work in cottage industries as unpaid family labour.

\section{Trends of women's involvement in the economic activities in the rural area-}

In the rural setup women play a central role in agricultural production. Traditionally women have seen working in "non public" domains such as selection of seeds and storing of crops as well as being largely responsible for the production of house hold produce and key care taker of domestic livestock. The social norm and customs limits women to remaining in the immediate household area and restrict women's mobility and in turn women's labour market opportunities. Also women therefore do not take the produce to the market and interact in public with men and have to rely on male family members or on middlemen for the sell of their product.

However due to the change of norm are now gradually changing and so do role of women's. More and more women are now actively visibly engaged in "public" employment in field work as wage day labourer, 
particularly amongst the poorer households in addition to their household task to supplement family income. Increasing levels of male internal and external migration is also held responsible to increasingly visible women's participation in non - traditional agricultural employment (ADB, 2004).

\section{Trends of women's involvement in the economic activities in the urban area -}

In urban areas, traditional attitudes towards women taking up wage employment tend to break down. The demand for cheap female labour in the manufacturing sector draws primarily poor, young women who have recently migrated from rural areas. These women represent a large pool of unskilled labour. Wage rates in these female-dominated sectors are generally lower as there is strong downward pressure on costs from international competition and because the pool of available labour is so large. For the majority of women this also tends to be their first employment so they have limited or no negotiating skills for wages or piece rates. Despite the low levels, studies have shown that women save a higher proportion of their wages and remit it to their families more regularly than men do.

Table 2: Employment in the Ready Made Garment Sector, Bangladesh

\begin{tabular}{|c|c|c|c|c|}
\hline Year & Male & Female & $\begin{array}{c}\text { Female as \% of total } \\
\text { employment }\end{array}$ & Total \\
\hline $1991-1992$ & 8,730 & 494,700 & 85 & 582,000 \\
\hline $1997-1998$ & 150,000 & 135,000 & 90 & $1,500,000$ \\
\hline
\end{tabular}

Source: BGMEA cited in CPD (2001), page 322.

The manufacturing and the ready made garment sector (RMG) witnessed a considerable growth in female labour force participation in the 1990s. The RMG sector emerges as the most important employment sector for women's not only in the urban areas but also for the whole country as it employs 1.35 million women (or $90 \%$ of the workforce). However women employed in the RMG sector employed in lower paid, lower skilled areas with little decision - making responsibility. Women are also often the first to lose their jobs in this and other export - oriented sectors where job cut of the labour market is a very common scenario in response to market fluctuations - even some times with out having any compensation or prior notice.

The expansion of telecommunication, banking, insurance and other private corporate organisation also become the entry point of increasingly large number of women with high education qualification. But the exact number of women employed in these sectors is not known due to lack of statistical information.

In order to meet the lucrative demand of overseas employment opportunities women now also have been migrated overseas although they 
are still only a small proportion of all migrants. However there have been many cases where Bangladeshi women have been grossly exploited or trafficked in to difficult circumstances once they have arrived in the receiving country.

\section{Trends of Women's participation in self - employment -}

Women's are also cornered in the field of self employment. Only fewer women (26.9\%) defined themselves as self employed in contrast to their male (51.9\%), attesting to the considerable obstacles faced by women in starting up small business (Bankengruppe, 2006). In particular, many women are unable to meet collateral requirements, have business training and advisory support services. Although the establishment of small and medium sized enterprises (SME's) in Bangladesh has consistently been identified as one of the most promising ways to diversify the economy and create employment programs - it therefore not adequately consider and /or address ways in which women's participation could be more actively supported and expanded. The fate of the microfinance programs targeting the welfare of the women often become blurred due to the lack of control by the women over the money received.

\section{Trend of Women's involvement in public sector employment -}

In 1976 the government introduced a mandatory 10\% quota for women in all its ministries, directorates, and autonomous bodies. This target was almost met as women filled 9.7\% of positions in all categories in 2002 (BBS, 2002). The proportion has hardly changed since 1988 when $7.3 \%$ of all categories of positions were filled by women. It should be noted that only one woman held the rank of secretary or additional secretary out of total of 62 positions in 2002, but women held $17.2 \%$ of assistant secretary positions. While it is important for women to be offered employment in public institutions on an equitable basis (and 10\% can hardly be considered equitable), it is also important that women hold senior decision-making positions. The presence of women in visible senior government positions expected to provide important role models to other women, changes male attitudes about women's competencies, and potentially influences the pattern of decision making on issues of importance to all women. 


\section{Disparity in women's participation in economic activity -}

Table 3: Average female wages as a percentage of average male wages

\begin{tabular}{|c|c|}
\hline Sector & 1998 \\
\hline Agriculture & $71 \%$ \\
\hline Manufacturing & $35 \%$ \\
\hline RMG & $66 \%$ \\
\hline Self employed & $37 \%$ \\
\hline Average across all sectors & $51 \%$ \\
\hline
\end{tabular}

Source: Developing a Policy Agenda for Bangladesh, CPD, 2001

Apart from the social construction, norms and beliefs as mentioned before - that creates barrier in women's participation in the economic activities - there also exists considerable disparity in men's and women's wage rate in Bangladesh although the principle of equal wages for equal work is guaranteed by law. On average women's wage rates are considerably lower than men even in same job and in almost all sectors (Table: 3). The 2000 Labour Force Survey (LFS) shows women's earnings to be approximately $58.5 \%$ of men's. Furthermore whereas $61 \%$ of female salaried workers earn less than 1000 taka per month, only 16\% of their male counterparts earn an equivalent amount - confirming entrenched wage based gender discrimination. Women's are concentrated more in higher number in the low paid work as compared to their male counterpart and vice versa (Table: 4) (BBS, 2002).

The most recent study (Kapsos, 2008) on gender wage gap shows that women earn an average percent less per hour than men. Controlling for difference in age, educational background, industry, occupation and geographic location, yields an estimated gender wage gap of $15.9 \%$, but including the effects of industrial and occupational segregation in to the estimate yields an estimated wage gap of 23.1 percent. Industrial segregation increases the overall wage gap by an estimated 7 percentage points. Gender gaps are observed in every industry, across all levels of education and in every establishment size class, with the largest gaps observed in the hotels \& restaurants and construction industries, among workers with primary education or less, and in mid-sized establishments. Gender-based occupational segregation increases the gender wage gap in the construction, financial intermediation and manufacturing industries, but mitigates it in the education, hotels \& restaurants and other services industries. The results make clear that increased education has an important role to play to lower the gender wage gap in Bangladesh: the largest gender gap is observed among illiterate workers and the second largest gap is observed among literate workers with less than a primary school education. 
Table 4: Percent of paid salaried workers by Monthly Income, Sex and Residence; 1999-2000

\begin{tabular}{|c|c|c|c|c|c|c|}
\hline \multirow{2}{*}{ Monthly income in taka } & \multicolumn{2}{|c|}{ National } & \multicolumn{2}{c|}{ Rural } & \multicolumn{2}{c|}{ Urban } \\
\cline { 2 - 7 } & Women & Men & Women & Men & Women & Men \\
\hline $1-750$ & 41.7 & 7.3 & 54.2 & 9.7 & 32.6 & 4.7 \\
\hline $751-1000$ & 19.2 & 8.9 & 18.5 & 12.1 & 19.9 & 5.3 \\
\hline $1001-1500$ & 10.6 & 10.2 & 7.7 & 13.2 & 12.8 & 6.8 \\
\hline $1501-2000$ & 6.7 & 13.1 & 2.9 & 13.4 & 9.6 & 12.8 \\
\hline $2001-2500$ & 3.2 & 7.5 & 0.6 & 7.9 & 5.0 & 7.0 \\
\hline $2501-3000$ & 5.9 & 14.5 & 5.4 & 13.7 & 6.3 & 15.5 \\
\hline $3001-3500$ & 2.2 & 5.8 & 2.9 & 5.2 & 1.7 & 6.5 \\
\hline $3500-4000$ & 5.0 & 9.4 & 6.0 & 8.5 & 4.3 & 10.3 \\
\hline $4001-5000$ & 2.1 & 9.2 & 1.8 & 8.7 & 2.1 & 9.8 \\
\hline $5001-7500$ & 1.9 & 8.0 & 0.0 & 5.3 & 3.2 & 10.9 \\
\hline $7501-10000$ & 0.8 & 3.9 & 0.0 & 1.7 & 1.3 & 6.3 \\
\hline $10001+$ & 0.7 & 2.2 & 0.0 & 0.6 & 1.2 & 4.1 \\
\hline
\end{tabular}

Source: LFS, 1999 - 2000, BBS

\section{Consequences of disparity in women's economic activity:}

In the last 10 years the overall poverty levels have declined. Growth in GDP has been averaging 5\% per year, and consumption-based measures indicate that poverty is declining. There has been a reduction in the proportion of the population living below the poverty line from $55.0 \%$ in 1985 to $44.7 \%$ in 1999.17 Urban areas had much higher growth in average income but also had considerable increases in income inequality. Most of the poor continue to reside in rural areas where income inequalities are less severe.

The major contributors to household income are assumed to be males as the primary wage earners, and generally little analysis is given to different types of contributions from women. Women are increasing their participation in non - agricultural wage labour and continue to make significant contributions to agricultural production through unpaid labour not counted in GDP calculations. There are also considerable savings in expenditures provided by women's domestic work such as caring for the sick, preparing food, and performing other domestic tasks.

The analysis goes on to correlate these widening gaps with the feminization of extreme poverty and cites higher incidences of both in rural areas. The wage disparity gives the poverty level a gender dimension as female headed households face more serious poverty, in terms of food insecurity and lower income, than male headed households. About $45 \%$ of female - headed households fall below the poverty line, compared to $39 \%$ of male headed household (UN, 2005), highlighting the difficulties women face in benefiting from economic growth. The average monthly income of 
female-headed households (FHHs) in rural areas is approximately 35\% lower than that of male headed households ( $\mathrm{MHH}$ ) and is 33\% less in urban areas. However, care has to be taken when considering FHHs as a target for poverty reduction. Women living in households headed by men also have difficulty in accessing and controlling the assets required to increase their incomes.

\section{Conclusion}

Despite increases in the number of women in the paid workforce in Bangladesh, there remain many areas where gender disparities are marked in the form of social norms, lack of employment opportunity, access to skills, logistic supports and so on. The gap in wages between men and women is still significant in all sectors, both formal and informal. However the impact of increasing women's participation in economic activity correlates to a range of positive benefits to the family. To promote women's economic equality government of Bangladesh has taken several steps including the withdrawal of a ban on women's employment abroad, building capacity in the newly established Ministry of Manpower Development and Export for providing security to women workers, and introducing a 60 percent quota in the recruitment of primary school teachers. However, other policy areas also need attention. For example, there is an urgent need for equal employment laws and equal wages for similar work outside the public sector. Again, while micro-credit programmes have benefited women economically, in order for them to graduate to the next economic stage, funds for small and medium size enterprise development must be made available to women entrepreneurs. Similarly, garment workers, especially women, should be given the option to participate in equity ownership in the garment sector. Furthermore, to forestall possible large-scale unemployment following the lapse of the Multi Fibre Arrangement from 2005, women garment workers need to receive skills development and vocational training that will equip them for employment in other existing and emerging sectors of the economy. In addition, to encourage the participation of women in the labour market, a proper working environment and facilities for women need to be established in the work place, nd day care centres should also be made available. A policy should be introduced that will help to gradually increase of female participation in the public sector to 50 percent (Amin, 2005).

\section{References:}

1. Asian Development Bank. (2004). Gender, Poverty and the Millennium Development Goals, Country Gender Strategy Bangladesh. Department, Asian Development Bank(ADB) - 
Bangladesh Resident Mission and Regional and Sustainable development.

2. Bankengruppe, K. (2006). Bangladesh Gender Profile - Discussion Paper 42. Resident Mission and Regional and Sustainable development Department.

3. Bangladesh Bureau of statistics. (2002). Bangladesh Labour Force Survey, 1999 - 2000. Bangladesh Bureau of Statistics(BBS).

4. Bangladesh Bureau of statistics. (2002). Statistical profile of Women in Bangladesh. Ministry of Women's and Children's Affairs and Bangladesh Bureau of statistics (BBS), Government of Bangladesh.

5. Eggen, C. (1998). Towards a strategy for women's programming in Bangladesh: the class and gender analysis; CIDA's programme and work plan. Paper prepared for country program analyst of CIDA.

6. Jahan, R. (1989). Women and development in Bangladesh: challenges and opportunities. Ford Foundation Bangladesh, Dhaka.

7. Kabeer, N. (2012). Economic Empowerment and Inclusive Growth: Labour Markets and Enterprise Development. Centre for Development Policy and Research, Discussion Paper 29.

8. Kapsos, S. (2008). The gender wage gap in Bangladesh. ILO Asia Pacific Working Series. International Labour Organization Regional Office for Asia and the Pacific, Bangkok. .

9. Klasen, S., \& Pieters, J. (2012). Push or Pull? Drivers of Female Labour Force Participation during India's Economic Boom. Institute of Labour Studies (IZA), Discussion Paper No. 6395.

10. Rahman, I. R., Islam, R (2013). Female labour force participation in Bangladesh: trends, drivers and barriers. ILO Asia- Pacific Working Paper Series.

11. Islam, R. (2011). The Employment Challenge in Developing Countries during Economic Downturn and Recovery. From the Great Recession to Labour Market Recovery: Issues, Evidence and Policy (London and Geneva, Palgrave Macmillan and ILO).

12. Amin, S. (2005). Selective inclusion or active discrimination? Women and Labour Market in Bangladesh. Chapter 12, Emerging Issues in Bangladesh Economy: A Review of Bangladesh's Development 2005-06, Dhaka.

13. United Nation (2005). Millennium Development Goals. Bangladesh Progress Report 2005. Bangladesh Government and UN Country Team in Bangladesh, Dhaka. 